\title{
Uma nobreza não muito regional. O papel político e social dos infanções de Astorga na primeira metade do século XI (1028-1065)
}

\author{
Jose Alexandre Sousa ${ }^{1}$ \\ Universidade de Salamanca \\ josealexandresousa@usal.es
}

RESUMO: Através da documentação temos conhecimentode vários momentos de instabilidade nas terras ocidentais do reino leonês depois da morte de Afonso $V$, em particular durante o intervalo que antecedeu a sagração do seu filho como o futuro Vermudo III. Contudo, alguns destes episódios já estariam a medrar em tempos anteriores no seio de diferentes actores sociais, entre os quais, certos membros de familias condais, como Rodrigo Romaniz, e alguns dos "infanzones terrae" de que nos falam esses mesmo documentos, como Ecta Rapínatiz y Ero Salítiz.

Estes membros das familias da nobreza local que aqui escolhemos analizar e acompanhar caracterizam-se por deterem uma certa autoridade nas suas áreas de influência —-sendo mesmo uma companhia frequente no séquito dos membros das famílias condais-, pela mobilidade da sua actuação política e pelo protagonismo em muitos e variados episódios que atentam contra o património alheio, particularmente clerical. A chegada ao trono de Fernando I trouxe uma certa ordem social aos diversos territórios do reino, com a devolução voluntária, e em certos casos forçada, das propriedades entretanto usurpadas.

Palavras Chave: Vermudo III; infanções; usurpações; monasteiros; Ero Salítiz; Astorga.

Una nobleza no muy regional. El papel político y social de los infanzones de Astorga en la primera mitad del siglo XI (1028-1065)

RESUMEN: A través de la documentación tenemos conocimiento de varios momentos de inestabilidad en las tierras occidentales del reino leonés después

\footnotetext{
${ }^{1}$ ORCID iD: https://orcid.org/0000-0003-2475-6665.
} 
de la muerte de Alfonso $V$, en particular en el intervalo que antecedió a la consagración de su hijo como el futuro Vermudo III. Sin embargo, algunos de estos episodios se estarían gestando desde tiempo atrás por diferentes actores sociales, a saber, ciertos miembros de familias condales, como Rodrigo Romaniz, y algunos de los infanzones terrae de que nos hablan esos mismos documentos, como Ecta Rapínatiz y Ero Salítiz.

Estos miembros de las familias de la nobleza local que aqui elegimos analizar se caracterizan por la detentación de la autoridad en sus áreas de influencia - siendo una compañía frecuente de los miembros de las familias condales-, por la movilidad de su actuación política y por protagonizar muchos y variados episodios que atentan contra el patrimonio ajeno, especialmente clerical. La llegada al trono leonés de Fernando I traerá cierto orden social a las tierras del reino, con la devolución, voluntaria o forzosa, de varias de estas propiedades a la iglesia.

PALABRAS ClAVE: Vermudo III; infanzones; usurpaciones; monasterios; Ero Salítiz; Astorga.

A not very regional nobility. The political and social role of the local Astorga aristocracy in the first half of the eleventh century (1028-1065)

ABSTRACT: Documents show several moments of instability in the western lands of the Kingdom of León after the death of Alfonso V, particularly in the interval that preceded the consecration of his son as the future Vermudo III. However, some of these episodes had been in the making for some time as a result of the actions of various social actors, including certain members of comital families like Rodrigo Romaniz, and certain infanzones terrae to which the same documents refer, including Ecta Rapinatiz and Ero Salitiz.

The members of the local nobility analysed here are characterized by the authority they wield in areas of influence - they frequent the company of comital nobility - by the mobility of their political action and for leading many and varied episodes that constituted an attack on the property of others, especially the clergy.

The accession to the throne of Fernando I was to bring some sense of social order to the lands of Leon, with the voluntary or enforced return of a number of these properties to the church.

KEY WORDS: Vermudo III; local aristocracy; land takeover; monasteries; Ero Salítiz; Astorga.

CÓMO CITAR ESTE ARTÍCULO/CITATION: Sousa, Jose Alexandre, «Uma nobreza não muito regional. O papel político e social dos infanções de Astorga na primeira metade do século XI (1028-1065)», Hispania, 79/261 (Madrid, 2019): 11-39. https://doi.org/10.3989/ hispania.2019.001. 


\section{INTRODUÇÃo}

Como temos vindo a observar ao longo da história do reino asturiano e astur-leonês, a efetividade do poder real, particularmente em momentos de instabilidade ou rutura, assume uma forma orgânica e pouco uniforme em termos territoriais, variando entre uma relativa representatividade baseada no seu berço físico e político e a pretensão reivindicativa sobre as demais geografias que compõem historicamente o reino. Essa observação é particularmente plasmável na documentação notarial, de certa forma a reconhecer a percepção vigente no entorno do cartório onde a mesma teria sido expedida.

Um exemplo dessa leitura, apesar de nunca se questionar a legitimidade do filho de Afonso $\mathrm{V}$ enquanto seu sucessor e herdeiro da coroa de Leão, mas fruto das circunstâncias políticas então vividas, é a titulação de Fernando e Sancha como reis de Leão (ou em Leão) antes da morte de Vermudo III a 4 Setembro de 1037, como se observa em alguns documentos emanados de centros eclesiásticos localizados nas terras orientais do reino ${ }^{2}$.

Em contraste com a prova documental, a narrativa presente na História Legionensis (chamada Silense) apresenta-nos Fernando somente a ser entronizado em Leão a 22 de Junho de 1038, «Era MLXXVI, X kalendas Iulii consacratus dominus Fredinandus in ecclesia beate Marie Legionensis, et unctus in regem.... $\rangle^{3}$, no entanto, e em complemento do atrás exposto, a sua postestas já se fazia sentir em algumas geografias do reino, capitalizando, neste caso, a vitória em Tamarón ${ }^{4}$.

Se nas regiões orientais do reino as suas pretensões foram rapidamente reconhecidas, até mesmo com anterioridade à morte do rei de então, no extremo ocidental, nomeadamente nas terras galegas e portuguesas, a conjuntura política e social levará um certo tempo a acamar a nova dinâmica política, com um primeiro documento dessas terras a fazer menção à efectividade da nova dinastia somente em Fevereiro de $1042^{5}$. Este reconhecimento tardio poderá ser sintomático de algo que se vinha repetindo periodicamente aquando da mudança de monarca, não um fenómeno capaz de balancear a própria monarquia, mas uma sensação de ausência de autoridade que leva às tais alphatenas entre os membros da nobreza e demais usurpações patrimoniais levadas a efeito por certos indivíduos sobre património alheio.

2 A 24 de Fevereiro de 1036, num documento do mosteiro de San Millán de la Cogolla, BECERRO GALICANO..., e a 1 de Junho de 1037, num documento (XXIX) do mosteiro de San Pedro de Arlanza. SERRANO, 1925: 63-66.

${ }^{3}$ HISTORIA SILENSE, 1921: 67.

${ }^{4}$ GARCÍA LARRAGUETA, 1962: 155-158. SERRANO, 1925: 66-69.

5 PORTUGALIA MONUMENTA HISTORICA..., 1869, vol. II: 192. 
O tema que nos propomos acolher neste estudo, para além da análise de situações já amplamente conhecidas, até devido ao relevo documental onde as mesmas se inserem, prende-se com a mobilidade geográfica de alguns dos membros das famílias da aristocracia local desta região central entre as terras leonesas e galegas, reconhecendo, de alguma maneira, a sua importância política. Se as acções e o percurso dessas individualidades, como Ecta Rapinátiz, Ero Salídiz, Pelagio Danieliz, entre outros, ficarão indelevelmente marcados pelas apropriações indevidas, serão essas mesmas acções a remeterem-nos para um papel social de relevo junto das respectivas comunidades, seculares e religiosas, com alguma anterioridade aos factos narrados nos documentos, em que, sentindo a agitação política no seio do reino, marcado pela morte de Afonso $\mathrm{V}$ e a subida ao trono do seu jovem filho Vermudo, deram expressão prática às suas ambições.

Esta nobreza local, em virtude do seu aparente restrito raio de acção, mostra-se na documentação por nós analisada uma ampla mobilidade, acompanhando na sua itinerância alguns membros das famílias condais, mas especialmente, revestindo-se de uma mobilidade per se, demonstrando uma predominância e um relevo social que ultrapassam as suas tradicionais fronteiras geográficas. Como enquandramento e por uma questão de fluidez analítica iremos observar, ainda que com uma maior amplitude cronológica, vários grupos de infanções protagonistas da vida social e política no ocidente leonês, de Santiago a Portugal, não deixando, já de seguida, de procedermos a uma sucinta análise dos principais acontecimentos políticos vividos nesta região, nunca esquecendo a pressão levada a efeito por Sancho III que, no nosso entender, exponenciaram a afirmação e o relevo destas famílias.

\section{DiNÂMICA POLÍTICA DA NOBREZA CONDAL NO OCIDENTE LEONÊS}

Não iremos mencionar a totalidade destes momentos de tensão social que a documentação nos revela aquando da transição dinástica, mas somente, e a título de exemplo, alguns deles mais significativos e que melhor ilustram esse mesmo ambiente protagonizados por elementos da aristocracia condal ou com ela aparentados, no sentido de melhor enquadrar o papel político das famílias de infanções que, linhas adiante, iremos tratar. A sua dimensão e impacto foram de tal envergadura que o alarme por eles provocado levaram a que vários instrumentos notariais os relatassem para a posterioridade. Num documento régio produzido em Astorga, e a título de exemplo, podemos verificar que, «Post mortem (...) regis surrexerunt in regnum suum viri peruersi veritatem ignorantes et exterminauerunt atque vitiauerunt hereditates ecclesiae.... ${ }^{6} \mathrm{e}$,

\footnotetext{
${ }^{6}$ CAVERO DOMÍNGUEZ y LÓPEZ, 1999, vol. I: 256-259.
} 
numa geografia mais excêntrica, neste caso na região do mosteiro de Celanova, «Post mortem ipsius domni Adefonsi in illa terra alfetana multa».

Um desses episódios e aproveitando a incerteza descrita linhas acima, foi protagonizado por Oveco Rudesíndiz ${ }^{8}$, que recusando-se a aceitar a autoridade da rainha regente ${ }^{9}$, e posteriormente a do próprio rei, vira parte do seu património ser alvo de $\operatorname{arresto}^{10}$, incluindo a sua tenência do castelo de Aguilar. Desconhecemos as vicissitudes pelas quais esta fortificação passou após a sua entrega à catedral de Lugo em virtude da anterior revolta de Sueiro Gundemáriz que, pelos vistos, seria regida por Oveco Rudesíndiz durante parte do reinado de Afonso $\mathrm{V}$, reconhecendo, de certa forma, a influência social e política deste personagem. Esse mesmo reconhecimento seria posteriormente atestado numa época em que o seu comportamento insubmisso aparentemente estaria sanado, pois vamos encontrá-lo a representar a infanta D. Sancha, filha de Vermudo II, num pleito contra essa mesma instância religiosa pela posse de uns servos a 2 de Novembro de $1038^{11}$.

Outro dado a reter, e num documento de doação redigido a 30 de Junho de 1051, do qual somente temos notícia, o bispo de Lugo D. Pedro menciona uma doação, em data incerta, de uma propriedade à sua pessoa por parte do mesmo Oveco Rudesíndiz ${ }^{12}$, o que evidencia, a par dos anteriores momentos acima mencionados, uma estreita relação política entre este magnate e a região lucense. Num determinado momento, mas seguramente antes da supressão patrimonial levada a cabo em Janeiro de 1029, Oveco recolhe-se debaixo da protecção de outro nobre galego, o conde Rodrigo Romaniz ${ }^{13}$. Este conde, por sua vez, culmina com uma rebelião activa o seu aparente antagonismo contra Vermudo III em Agosto de 1032, nessa mesma região, contanto para tal com contingentes orientais ${ }^{14}$.

7 ANDRADE CERNADAS, 1995, tomo II: 735-737.

8 Segundo José María del Pozo e Carlos Baliñas, Oveco Rudesíndiz seria filho de Rosendo Gonçalves e neto de Gonçalo Mendes, no entanto, não nos foi possível até à data comprovar documentalmente a fiabilidade desta sugestão. FERNÁNDEZ DEL POZO, V (León, 1984): 162, nota 290. BALIÑAS PERES, 1988: 113-114, nota 183.

${ }_{9}$ Urraca, a segunda esposa de Afonso V e madrasta de Vermudo, irmã do rei de Navarra Sancho III.

${ }^{10}$ NÚÑ̃Z CONTRERAS, 4 (Sevilla, 1977): 447-449.

${ }^{11}$ LÓPEZ SANGIL y VIDÁN TORREIRA, 27 (Mondoñedo, 2011): 270-272.

12 FLÓREZ, 1796, tomo XLI: 162.

13 NÚÑEZ CONTRERAS, 4 (Sevilla, 1977): 447-449.

${ }_{14}$ NÚÑEZ CONTRERAS, 4 (Sevilla, 1977): 469-471. A presença de tropas de Navarra numa região tão ocidental do reino não é unânime ao nível da historiografia, muito em parte devido à cópia tardia do documento. Assim, Miguel Calleja Puerta propõem antes a leitura de «barones Galletie», em CALLEJA PUERTA, 2001: 802, nota 18. Referente ao capítulo I da Quarta Parte, p. 521 e Jose María Lacarra avança que seriam somente um grupo de «gascones», vindos do mar, aos quais Rodrigo Romaniz se teria aliado, in LACARRA, 1972, vol. 1: 208, nota 43. 
Apesar de se viver uma situação muito fluída por esses dias, não conhecemos com detalhe a razão que levou um dos nobres galegos mais influentes (suprinus ipsius Suarius Gundemarit), e leal servidor da coroa anterior, a protagonizar este movimento de rebeldia, pois o mesmo encontra-se junto de Vermudo III aquando da sua entronização em Santiago e com ele permanece até ao final do ano de $1028^{15}$. Não estamos seguros, mas temos razões para desconfiar que o seu antagonismo contra o rei já estaria, de certa maneira, bem latente, ou não fora Oveco Rudesíndiz contar com a sua protecção nos instantes iniciais de 1029. Alguns autores ${ }^{16}$, tendo presente o teor do documento que temos vindo a acompanhar, nomeadamente a passagem «uascones Galletie», colocam em evidência uma possível ligação e simpatia pelo rei Sancho III — bastante activo politicamente nestes dias - por parte de Oveco Rudesíndiz e Rodrigo Romaniz, no entanto, será a própria acção do primeiro que parece desmentir essa alegada simpatia, pois o mesmo revolta-se contra a madrasta do jovem Vermudo III. Quanto ao posicionamento de Rodrigo Romaniz, e se o mesmo fosse partidário da causa de Navarra, pensamos que será pouco certo o apoio a um declarado opositor da irmã de Sancho III.

Em ângulo totalmente oposto encontra-se Martínez Diéz ${ }^{17}$, que comungando da opinião de Lacarra ${ }^{18}$, apresenta-nos uma visão mais conciliadora e apaziguadora do papel de Sancho Garcês no conjunto do reino de Leão, que por intermédio da sua irmã visava a estabilização social (tutela?) nos turbulentos anos da menoridade de Vermudo III. Nessa política enquadrava-se a instalação de uma guarnição militar no alpe uocitato Lapio, no território de Lugo, e centro da oposição galega à nova dinâmica e cujo maior protagonista teria sido precisamente Rodrigo Romaniz ${ }^{19}$.

É inegável a pressão política de Sancho III sobre as terras ocidentais, como fica patente na leitura de várias fontes documentais, «... Regnante rege Sanctio in Pampilonia et in Ceia...», diz-nos um documento do mosteiro de Sahagún de Novembro de $1033^{20}$, bem como, nas fontes narrativas, como uma notícia contida nos Annales Castellani Recentiores, «In era $M^{a} L X X^{a} I I$ (a. 1034) presit Sancius rex Astorga $\rangle^{21}$, no entanto, e não querendo menosprezar a incisiva influência política de Sancho III nesta região, mas tendo presente a crítica

15 NÚÑEZ CONTRERAS, 4 (Sevilla, 1977): 441-446.

16 Entre outros, SÁNCHEZ CANDEIRA, 1999: 54. FERNÁNDEZ DEL POZO, V (León, 1984): 162. Parcialmente, CALLEJA PUERTA, 2001: 521.

17 MARTÍNEZ DÍEZ, 2007: 163-164.

18 LACARRA, 1972, vol. I: 213-215.

19 MARTÍNEZ DÍEZ, 2007: 164. Deste modo o autor, e a crer nas palavras do copista, pretende harmonizar a existência de tropas orientais numa região algo distante da sua proveniência.

${ }^{20}$ HERRERO DE LA FUENTE, 1988, vol. II: 89-90.

${ }^{21}$ MARTÍN IGLESIAS, 4 (Oviedo, 2009): 216. 
documental abordada por Isla Frez ${ }^{22}$, deveremos olhar para toda esta conjuntura com alguma prudência face à nebulosidade que a envolve, pois a acompanhar Vermudo III nos primeiros meses de $1034^{23}$, numa deslocação à região de Sahagún, encontram-se igualmente alguns dos principais membros da nobreza leonesa (como o bispo de Leão, Servando, Gutier Afonso, Munio Afonso, entre outros), e que irão no reinado seguinte desempenhar um importante papel no equilíbrio regional.

Igualmente nesse ano, mas em momento incerto, um documento da catedral de Lugo faz nota a certos fideles do rei, Álvaro Ordonhes, Rodrigo Ordonhes, Pedro Flaínez, Oveco Vermudes e Nepociano Osóres, que na sua companhia se encontram ante a presença do bispo titular, D. Pedro, para lhe prestarem juramento de, em conjunto, não importunarem o património da sua igreja ${ }^{24}$. $\mathrm{Na}$ nossa opinião, podemos olhar para este momento como uma tentativa de envolver o bispo na sua causa, assegurando-lhe, para além da inviolabilidade e da protecção das suas propriedades, o respeito pela autonomia da sua potestas dentro da respectiva cidade e castelo ${ }^{25}$. E como se disse, numa época de forte dinâmica política e social, em que anos antes, concretamente em Janeiro de 1027, parte dos registos da própria Sé foram destruídos num incêndio ${ }^{26}$, não deixando de ser relevante tal acto de protecção régia. Perante este cenário o rei compromete-se a si, mas igualmente aos nobres que o acompanham, demonstrando deste modo alguma vitalidade política em que um conjunto das mais importantes famílias do reino se sujeitam a não hostilizar as suas propriedades. A originalidade deste documento radica precisamente nesta aparente simbiose entre o rei e estes nobres, pois, o papel de defensor protagonizado por Vermudo III, e pelos reis anteriores, chocava com as pretensões dessa mesma nobreza sobre o património eclesiástico.

Mais para Sul, nos confins dos finibus Gallecie e zona de contacto com a realidade política e social islâmica, a conjuntura, apesar da fraca presença documental, não poderia ser menos fluída. Nesse sentido, e para melhor ilustrar e enquadrar esta situação, teremos de recuar até pouco depois da subida ao

${ }^{22}$ Amancio Isla Frez chama-nos à atenção para uma pertinente crítica documental que importa fazer antes de assumirmos como certas a totalidade das informações que os documentos objecto de estudo nos poderão fornecer, nomeadamente a tutela territorial exercida pelos diferentes monarcas. Por serem maioritariamente cópias tardias, esses registos poderão encontrar-se adulterados à posteriori aos acontecimentos neles relatados, principalmente em relação à potestas régia exercida na região envolvente ao cartório que os expediu. Convém ter igualmente presente a proveniência da documentação e a sua proximidade ao berço regional do monarca em causa. ISLA FREZ, 1999: 133-136.

23 HERRERO DE LA FUENTE, 1988, vol. II: 90-91.

${ }^{24}$ NÚÑEZ CONTRERAS, 4 (Sevilla, 1977): 482-483.

${ }_{25}$ NÚÑEZ CONTRERAS, 4 (Sevilla, 1977): 482-483.

${ }^{26}$ LÓPEZ SANGIL y VIDÁN TORREIRA, 27 (Mondoñedo, 2011): 55-58. 
trono de Afonso V, neste caso, ao ano de 1008, ano da morte do comite maior Mendo Gonçalves, tutor e sogro do jovem rei.

A morte de um dos condes mais poderosos e influentes no seio do reino causa-nos a nós, observadores distantes de tais vicissitudes, mais impacto e espanto do que aparentemente causou aos seus pares, pois o seu assassinato apenas ficou para a posteridade com uma simples linha: «Era 1046, $2^{a}$ nonas octobris occisus fuit comes Menendus» ${ }^{27}$, não tendo o seu relator nos deixado qualquer informação adicional, nem quanto aos protagonistas, nem quanto às causas; de facto, e ao contrário do que supõe Gonzaga de Azevedo ${ }^{28}$, a sua simplicidade somente nos transmite o modo violento como a mesma fora praticada por terceiros. Apesar de ser significativo a ausência do motivo, sabemos que a conjuntura vivida neste primeiro quartel do século XI nesta faixa atlântica não se afigurava fácil.

Em anos sucessivos, ou com uma periodicidade bastante assombrosa, bandos normandos, usando de forma expedita as suas ágeis embarcações, assolam o litoral e as terras adjacentes ${ }^{29}$, exercendo uma pressão bastante incisiva nas autoridades leonesas no sentido de conter e debelar tal insegurança, como observamos na morte do conde portucalense Alvito Nunes em Setembro de 1016 no decurso de uma dessas incursões, neste caso, sobre o castelo de Vermoim $^{30}$. Apesar de desconhecermos a total abrangência das razias normandas nesta costa ocidental do reino, as mesmas, de acordo com as variadas fontes conhecidas, são significativas pela sua constância e pelo impacto na vida social e política destas paragens. Para além dos resgates pagos por familiares dos cativos, e pelo seu natural empobrecimento, elas trouxeram, a par das campanhas de Almançor, uma certa desorganização territorial, como ficou patente na desagregação da diocese de Tui e a sua posterior inclusão na de Iria/Santiago em $1024^{31}$.

Após a morte do conde Alvito Nunes sucedeu-lhe no governo da terra portucalensis o seu filho Nuno Alvites, registado para a posterioridade como

27 DAVID, 1947: 295.

${ }^{28}$ Luís Gonzaga de Azevedo defende a sua morte às mãos dos normandos, no entanto, a sua argumentação não é a mais verosímil face aos documentos em que a mesma se sustenta, pois nada neles, nem na Chronica Gothorum, alguma vez mencionam estes piratas nórdicos como correlacionados com o falecimento de Mendo Gonçalves. GONZAGA DE AZEVEDO, 1939, vol. II: 117, nota 2 e Apêndice X: 165.

${ }_{29}$ Para uma leitura global e recente sobre a presença dos povos do Norte europeu nas costas peninsulares podemos consultar, de entre outras obras, Hélio Fernando Vitorino Pires, Incursões Nórdicas no Ocidente Ibérico (844-1147): Fontes, História e Vestígios, dissertação inédita de doutoramento em História Medieval, Faculdade de Ciências Sociais e Humanas da Universidade Nova de Lisboa, 2012.

${ }^{30}$ DAVID, 1947: 295.

${ }^{31}$ LUCAS ÁLVAREZ, 1998: 152-154.

Hispania, 2019, vol. LXXIX, nº 261, enero-abril, págs. 11-39, ISSN: 0018-2141, e-ISSN: 1988-8368 
magnus comes, vindo este a falecer poucos anos depois em $1028^{32}$. No decurso da sua morte os destinos da administração do condado serão entregues ao seu filho primogénito, no entanto, em virtude da tenra idade do mesmo, a sua mãe Ilduara assumirá os destinos do condado ${ }^{33}$. Será, então, neste interregno de afirmação e consolidação condal que um membro da nobreza regional, Gonçalo Trastamires, com recursos próprios, ocupa militarmente o castelo de Montemor, situado estrategicamente sobre o rio Mondego, entre o litoral e Coimbra, em Novembro de $1034^{34}$.

Igualmente nesse mesmo ano de 1034, e de forma recorrentemente sumária, seria assassinado nas margens do rio Guetania um certo conde Mendo ${ }^{35}$. Nada sabemos sobre a respectiva identidade patronímica, no entanto, alguns autores $^{36}$ propõem a sua identificação com o conde portucalense Mendo Nunes, filho de Nuno Alvites, identificação essa que se revela, na nossa opinião e corroborando a emenda e sugestão de José Mattoso, pouco verosímil face aos variados documentos onde o mesmo consta após essa data ${ }^{37}$ e que provavelmente terá falecido antes de $1053^{38}$. Este autor avança, então, que a esse comes Menendus se corresponda Mendo Luz ${ }^{39}$, no entanto, e adensando as muitas dúvidas sobre este protagonista, esta última proposta, e a nosso ver, encontrase igualmente carente de dados que a solidifiquem, pois, e a crer na moderna correspondência do rio Guetanie com o actual afluente do Minho, rio Guetania ${ }^{40}$, local onde esse conde perecera, estaria algo distante da sua área de influência regional, que se situaria por estes dias na terra de Santa Maria, «... ille comes menendus luci qui illa terra inperabat» ${ }^{41}$, ressalvando o facto de uma das principais características da nobreza condal seria precisamente a mobilidade geográfica.

Ainda que de passagem, estes foram alguns dos episódios mais agressivos que caracterizaram da vida social e política destas terras ocidentais leonesas, cujos protagonistas poderemos situar no extrato social mais elevado da

32 DAVID, 1947: 295. A brevidade da fonte não nos permite descortinar mais pormenores que rodearam este acontecimento trágico, somente assinalando a coincidência com a morte de Afonso $\mathrm{V}$.

33 PORTUGALIA MONUMENTA HISTORICA..., 1869, vol. II: 193-194.

${ }^{34}$ DAVID, 1947: 295.

35 DAVID, 1947: 295.

${ }^{36}$ Nomeadamente, e entre outros, ALMEIDA FERNANDES, 82 (Guimarães, 1972): 62-63. GONZAGA DE AZEVEDO, 1939, vol. II: 118.

37 PORTUGALIA MONUMENTA HISTORICA..., 1869, vol. II: 193-194.

38 PORTUGALIA MONUMENTA HISTORICA..., 1869, vol. II: 234. MATTOSO, 1981b: 114.

${ }^{39}$ MATTOSO, 1981b: 114.

40 DAVID, 1947: 295-296, nota 6. Almeida Fernandes avança o rio Tea, igualmente afluente do Minho, como sendo a designação mais correcta. ALMEIDA FERNANDES, 82 (Guimarães, 1972): 62 , nota 1 .

${ }^{41}$ PORTUGALIA MONUMENTA HISTORICA..., 1869, vol. II: 230-231. 
aristocracia, contudo, e de acordo com as notícias conhecidas para estes anos que aqui nos debruçamos, os principais desmandos viriam a ser perpetrados pelos membros de uma aristocracia regional, que podemos identificar claramente com os tais infanzones terrae que nos fala um documento lavrado em Janeiro de $1046^{42}$.

\section{Mobilidade GEOGRÁfiCA E ACÇão POLítica da ARISTOCRACIA LOCAL}

Se nas linhas anteriores observámos o contributo possível de alguns dos principais condes e magnates destas terras ocidentais para todo este clima de insegurança e de perturbação social, os membros de uma aristocracia mais local e menos influente politicamente no conjunto do reino não deixaram de demonstrar toda a sua capacidade, onde os seus desmandos invocam, por vezes, a presença directa ou indirecta do monarca no sentido de posteriormente os solucionar e apaziguar.

Vimos que a transição entre monarcas é especialmente critica quanto à estabilidade política e social, onde a monarquia se presta a todo um conjunto de comportamentos e atitudes com vista ao equilíbrio das diferentes dinâmicas regionais, no entanto, este comportamento fica igualmente plasmado nas diferentes autoridades regionais, especialmente nos momentos de maior tensão.

Em Astorga, o seu bispo, particularmente Jimeno (992-1026), desempenhava esse papel, sendo que Afonso V nele delegava a sua autoridade para o desempenho de questões relevantes da governação desta região de fronteira, «Tunc dixit ille epíscopo ad eam qui potestatem acceperit a rege dare ueritatem inter eos $\rangle^{43}$, atestando, de certo modo, a sua relevância social. Jimeno provavelmente seria assassinado no decorrer do ano de $1026^{44}$, em circunstâncias que nos são desconhecidas, mas inseridas num contexto de forte agitação $0^{45}$. Seguir-se-á um interregno e um vazio da potestas em toda esta circunscrição, o que propiciou todo um conjunto de desmandos contra as propriedades clericais protagonizados por membros da aristocracia local e ampliados igualmente pela morte do rei em Agosto de 1028.

42 CAVERO DOMÍNGUEZ y LÓPEZ, 1999, vol. I: 254-256.

${ }^{43}$ RUIZ ASENCIO, 1987, vol. III: 418-419. Neste documento Jimeno encontra-se a presidir a um pleito pela posse de uma propriedade.

${ }^{44}$ DURANY CASTRILLO y RODRÍGUEZ GONZÁLEZ, 15 (sl, 2003): 202-205.

45 CAVERO DOMÍNGUEZ y LÓPEZ, 1999, vol. I: 296-299. Pelagio Conde foi quem provavelmente o assassinou, «... monasterios devastavi, rebus sancte ecclesia contempni et insuper magnum magna cogitavi ut dominum meum atque pontificem morti traderem...», in QUINTANA PRIETO, 1971: 113.

Hispania, 2019, vol. LXXIX, nº 261, enero-abril, págs. 11-39, ISSN: 0018-2141, e-ISSN: 1988-8368 https://doi.org/10.3989/hispania.2019.001 


\subsection{Ecta Rapinátiz}

Um desses protagonistas será Ecta Rapinátiz que em colaboração com os seus filhos irá roubar e queimar os registos da Sé de Astorga, apoderando-se posteriormente de várias das suas herdades ${ }^{46}$. Apesar de uma eventual origem familiar leonesa ${ }^{47}$, estaria, de certa maneira, vinculado à igreja de Astorga desempenhando o cargo de administrador das rendas ao tempo do bispo Jimeno (992-1026) ${ }^{48}$, prestando igualmente testemunho, entre os anos 1017 e $1020^{49}$, da devoção de vários fiéis para com o mosteiro de $\mathrm{S}$. Dictino no período anterior ao seu levantamento em rebeldia. Uma última nota sobre o seu percurso pessoal leva-nos até à região leonesa, onde iremos encontrá-lo a efectuar uma doação ao mosteiro de Matallana a 23 de Maio de $1028^{50}$, em pleno interregno dinástico.

Sobre o momento do seu falecimento não temos notícia sólida, somente uma pista que nos remete para um momento conflictuoso na região de Astorga, «Proter quod unusquisque ipsorum unus inter alios gladio se trucidauerint $\aleph^{51}$, no entanto, nada nos garante que a sua morte adveio neste episódio. Com relativa segurança pensamos que a mesma ocorrera perto do final do ano de 1031, assumpção essa baseada no facto de a 15 de Novembro de 1031 a sua esposa Domnigado, em conjunto com os seus filhos, Godesteu, Rapinato, Flaíno e Romano Ectaz, efectuarem em prol da sua alma a redacção de uma carta de ingenuidade a favor de Martim e dos seus filhos, e nela se encontrarem, como testemunhas e confirmantes da mesma, certamente em sinal de apresso pela família, alguns dos nobres

${ }^{46}$ CAVERO DOMÍNGUEZ y LÓPEZ, 1999, vol. I: 296-299. Embora o documento esteja datado do ano de 1028, Quintana Prieto, numa posterior análise a múltiplos aspectos nele contidos, atribuiu o ano de 1058 como sendo o mais correcto. RODRÍGUEZ, 1995: 397, nota 828. Citando in QUINTANA PRIETO, 1968: 536 e nota 179. No entanto, podemos balizar os factos nele descritos entre 1026, ano do assassinato do então bispo Jimeno e 1030, ano em que ingressa obispo Pedro Gundulfiz na respectiva diocese. Para uma melhor leitura deste período e compreender a dinâmica subjacente ao mesmo, ver: DURANY CASTRILLO y RODRÍGUEZ GONZÁLEZ, 15 (Santiago de Compostela, 2003): 187-222, particularmente entre as páginas 202-205.

47 DURANY CASTRILLO y RODRÍGUEZ GONZÁLEZ, 15 (Santiago de Compostela, 2003): 199-208. Os autores justificam esta provável naturalidade com o património detido pela sua família na região entre os rios Esla e Cea. RUIZ ASENCIO, 1987, vol. III: 447-448 e 509510. Verifica-se igualmente a aparente ausência de bens patrimoniais na região de Astorga, justificando, de certo modo, os actos lesivos para com a respectiva Sé levados a efeito pela sua família, apprehenderunt omnes scripturas, e cremaverunt eas.

${ }^{48}$ FLÓREZ, 1762, tomo XVI: 165.

49 CAVERO DOMÍNGUEZ y LÓPEZ, 1999, vol. I: 198-199 e 203-206.

${ }^{50}$ RUIZ ASENCIO, 1987, vol. III: 447-448. Sobre a relação deste documento com Ecta Rapinátiz temos de o olhar com alguma reserva, pois no mesmo somente o nomen «Rabinate» se menciona, deixando incógnito o seu sobrenomen.

${ }^{51}$ CAVERO DOMÍNGUEZ y LÓPEZ, 1999, vol. I: 256-259. 
leoneses mais proeminentes da época, caso do bispo de Leão, Servando, e Munio Rodrigues $^{52}$. Se consultarmos atentamente o arquivo da catedral de Leão, encontramos recorrentemente este último nobre em múltiplos dos seus documentos, mas o que queríamos chamar a atenção prende-se com a atractividade da região fronteiriça entre as terras leonesas e galegas que desperta junto de amplos sectores da aristocracia, para além do já mencionado Munio Rodrigues ${ }^{53}$, encontramos amiúde o conde Munio Fernandes ${ }^{54}$ a olhar de forma diligente para esta região.

Como se disse anteriormente, e resumindo a nossa linha argumentativa, o percurso pessoal de Ecta Rapinátiz termina com a morte que lhe sobreveio nos finais de 1031, no entanto, apesar desse mesmo percurso ser pontualizado por momentos de grande violência, a influência que a sua família detém em Astorga será determinante para a vida futura dos seus filhos, nomeadamente de Rapinato. Após a morte do seu pai, e de forma autónoma, Rapinato, acompanhado pelo seu irmão Flaíno, encontra-se presente a testemunhar uma transação de propriedades entre o novo bispo de Astorga, Pedro Gundulfiz (1041-1051), e o abade Sabarico do mosteiro de S. Pedro de Montes, a 14 de Março de $1043^{55}$. Nesse mesmo ano e igualmente numa escritura do mesmo mosteiro, encontramos Rapinato Ectaz a exercer a autoridade na terra de $\mathrm{Ulver}^{56}$, autoridade essa que se prolonga até, pelo menos, Maio de $1047^{57}$. Posteriormente, e de novo em conjunto com o seu irmão Flaíno, bem como, por um composto grupo dos principais nobres do reino, encontramo-lo em Janeiro de 1046 na presença dos reis Fernando e Sancha aquando da sua primeira deslocação à região de Astorga, onde, e a pedido do bispo local, devolve à respectiva Sé a villa de $\mathrm{S}$. Lourenço ${ }^{58}$, cujos direitos de propriedade lhe teriam sido usurpados por um conjunto de pessoas, entre as quais, alguns infanzones terrae ${ }^{59}$. Alguns anos mais tarde, concretamente a 27 de Outubro de $1049^{60}$, acompanhado de outros membros desta aristocracia periférica, iremos ver este nosso protagonista a testemunhar uma ampla doação ao mosteiro de Eslonza, naquilo que podemos considerar como, e de acordo com o seu percurso documental, a primeira e única incursão no exterior da sua área de influência regional. Sobre o seu significado e pertinência não nos iremos deter por agora numa possível conjectura, deixando-a para diante aquando da análise ao percurso mais abrangente de Ero Salídiz.

52 RUIZ ASENCIO, 1987, vol. III: 509-510.

${ }^{53}$ RUIZ ASENCIO, 1987, vol. III: 268-270; 1990, vol. IV: 119-120.

${ }^{54}$ RUIZ ASENCIO, 1987, vol. III: 121-122 e 211-213. CAVERO DOMÍNGUEZ y LÓPEZ, 1999, vol. I: 177-178.

${ }^{55}$ QUINTANA PRIETO, 1971: 100-101.

56 QUINTANA PRIETO, 1971: 101-102.

57 QUINTANA PRIETO, 1971: 102-103.

58 CAVERO DOMÍNGUEZ y LÓPEZ, 1999, vol. I: 254-256.

59 CAVERO DOMÍNGUEZ y LÓPEZ, 1999, vol. I: 254-256.

${ }^{60}$ RUIZ ASENCIO y RUIZ ALBI, 2007, vol 1: 117-121.

Hispania, 2019, vol. LXXIX, nº 261, enero-abril, págs. 11-39, ISSN: 0018-2141, e-ISSN: 1988-8368 https://doi.org/10.3989/hispania.2019.001 
Assim, e fazendo um breve interregno nesta composição sobre as acções de Rapinato Ectaz, temos a assinalar um acontecimento sobejamente conhecido que se teria desenrolado provavelmente no interregno dinástico e cuja resolução provavelmente se efectivou em Junho desse mesmo ano de 1046. O documento que nos dá luz sobre este episódio relata-nos novamente o bispo de Astorga, Pedro Gundulfiz, a solicitar, mais uma vez, o auxílio do rei no sentido de ver restituído património usurpado. Fernando irá ordenar a um seu oficial (palatio nostro fidelissimun saionem nostrum), Berino, que averiguasse as alegações do bispo. Após essas diligências, uma propriedade, que doravante se chamará Matantia em virtude das vicissitudes nela ocorridas, onde o mesmo Berino encontra a morte ${ }^{61}$, será de novo incorporada no património fundiário da Sé de Astorga.

Estes primeiros momentos que aqui transparecem de um relativo retorno à percepção de autoridade nestas terras de fronteira, onde se inclui naturalmente o restabelecimento patrimonial usurpado à Igreja, irá ser recorrente na acção da nova dinastia, umas vezes por averiguações in loco dos oficiais régios, como vimos, outras vezes, por livre iniciativa ${ }^{62}$ de quem se apoderou de tais propriedades. Será neste último caso, e retomando o caminho cronológico de Rapinato Ectaz, que se insere a acção da cunhada Marina, entretanto já viúva, e dos seus sobrinhos no sentido de devolverem todo um conjunto de herdades que o seu marido Flaíno se apropriou ilegitimamente. Este momento fora lavrado a 26 de Novembro de $1058^{63}$, ante a presença real, e nele se relata a acção predatória do seu sogro, à qual já nos referimos atrás. O que nos transparece da análise do documento é a individualização de quem, e após as escrituras notariais terem sido queimadas, se apropriou das herdades, neste caso, o seu marido Flaíno Ectaz ${ }^{64}$. Ou seja, somente após a sua morte e aparentemente sem o conhecimento do bispo de Astorga, Marina irá devolver-lhe as propriedades isentado, de certa forma, o seu cunhado, autoridade e protagonista político da terra de Ulver, dessa acção de presura agressiva, não se notando na documentação posterior qualquer censura pelo seu conluio familiar.

No ano seguinte, a 10 de Maio, Rapinato Ectaz encontra-se a testemunhar uma situação semelhante protagonizada por Sancha e a respectiva filha

${ }^{61}$ CAVERO DOMÍNGUEZ y LÓPEZ, 1999, vol. I: 256-259.

${ }^{62}$ Temos de nos resguardar da amplitude deste conceito, pois nada na documentação autoriza à sua aplicação em sentido lato, mas sem dúvida que a nova dinâmica política protagonizada pela nova dinastia terá um peso acrescido na percepção da autoridade nos diversos actores do espaço social que aqui escolhemos acompanhar.

${ }^{63}$ A 28 de Fevereiro desse mesmo ano iremos vê-lo a testemunhar uma doação de Aragunti, abadessa do mosteiro de S. Dictino, ao mesmo cenóbio. CAVERO DOMÍNGUEZ y LÓPEZ, 1999, vol. I: 293-294.

${ }^{64}$ CAVERO DOMÍNGUEZ y LÓPEZ, 1999, vol. I: 296-299. 
Adosinda, que ao procederem à doação de parte de algumas propriedades procuram deste modo «nostri criminis expauescimus» ${ }^{65}$. O documento é omisso quanto à posse anterior das propriedades em questão, ficando a dúvida sobre se as mesmas teriam sido pertença da igreja de Astorga ou património fundiário da família de Sancha. A par dessa doação, menciona-se igualmente o retorno das escrituras que teriam sido subtraídas do arquivo diocesano ${ }^{66}$. Finalmente, e mais uma vez na presença real, Rapinato Ectaz encontra-se a 5 de Outubro de 1063 numa cerimónia pública de agradecimento ao bispo de Astorga pelo trabalho realizado aquando da transladação dos restos mortais de S. Isidoro para a cidade de Leão, onde o mesmo recebe em doação o mosteiro de Santa Marta de Tera, entre outras propriedades e privilégios ${ }^{67}$.

Será nessa mesma região de Tera, e como apontamento final sobre o percurso desta família, que iremos observar anos mais tarde, um seu neto de nome Fernando Flaínez, filho de Flaíno, a proceder à entrega de uma herdade, e respectivas dependências, a título de doação ao mosteiro de Sta. Marta de Camarzana. A dita herdade encontra-se nas imediações da casa monástica e na notícia que lhe dá corpo ficamos igualmente a saber que a mesma teria sido incorporada no património da família de Fernando Flaínez mediante uma permuta efectuada com os antigos proprietários, um casal de nome Lourenço e Remesilde, que receberam, a par de um moinho nas imediações de Castrogonzalo, uma não especificada propriedade na região de Salamanca ${ }^{6}$. Apesar do nosso desconhecimento sobre a dinâmica fundiária desta família não deixa de ser relevante a dispersão desse mesmo património por uma abrangente geografia.

\subsection{Ero Salídiz}

Na mesma geografia periférica da diocese de Astorga, e aparentado com Ecta Rapinátiz $^{69}$, encontramos mais um provável membro dos tais infanzones

${ }^{65}$ CAVERO DOMÍNGUEZ y LÓPEZ, 1999, vol. I: 225-226. Este documento vem classificado e datado na colectânea documental em epígrafe do ano de 1029, no entanto, de acordo com o seu original contido no Tumbo Negro, a data que nele consta será o ano de 1059 . DURANY CASTRILLO y RODRÍGUEZ GONZÁLEZ, 15 (Santiago de Compostela, 2003): 210, acentuam várias características, entre confirmantes do documento, contexto descrito, etc., que apontam para o ano 1059 como o mais correcto.

${ }_{66}$ CAVERO DOMÍNGUEZ y LÓPEZ, 1999, vol. I: 225-226.

${ }^{67}$ CAVERO DOMÍNGUEZ y LÓPEZ, 1999, vol. I: 302-306.

${ }^{68}$ Indice de las escrituras de la S. Iglesia de Astorga dentro y fuera de los tumbos (Tumbo Negro de Astorga), Biblioteca Nacional Española, Madrid, Ms. 4357, fol. 167, n. ${ }^{\circ} 589$.

${ }^{69} \mathrm{O}$ filho de Ecta Rapinátiz, Flaíno Ectaz, estaria casado com Maria Eriz, filha de Ero Salídiz. Estas ligações familiares estão melhor deduzidas em: DURANY CASTRILLO y RODRÍGUEZ GONZÁLEZ, 15 (Santiago de Compostela, 2003): 214. 
terrae, de nome Ero Salídiz, a aproveitar novamente o interregno dinástico para se apropriar, em conjunto com os seus filhos, de uma propriedade da respectiva Sé, e das consequentes rendas e proventos, neste caso, do mosteiro de S. Pedro de Zamudia ${ }^{70}$.

Ao analisarmos a parca documentação disponível, após essa acção, onde Ero Salídiz se assume como protagonista na relação com S. Pedro de Zamudia, constatamos um padrão que poderemos interpretar como a constituição de um património pessoal centrado nesse mosteiro e nessa região aparentemente distante do berço familiar. A 25 de Outubro de 1039, mas em dois momentos distintos $^{71}$, e em conjunto com a totalidade do agregado famíliar, Ero irá proceder ao referido mosteiro uma ampla doação fundiária de propriedades concentradas na região do Bierzo ${ }^{72}$, embora arrendadas a terceiros ${ }^{73}$. Apesar desta apropriação as doações procedentes de particulares continuaram a fluir nos anos seguintes e ao nível da própria gestão currente deste mosteiro dúplice, a mesma continuaria a ser assegurada maioritariamente por abadessas ${ }^{74}$, configurando uma aparente normalidade na sua vida, tanto secular, como monástica, demonstrando, por parte da família de Ero, uma anterior proximidade para com este cenóbio e esta região.

Em relação ao seu percurso pessoal e familiar, e aquilo que a documentação disponível nos permite conhecer, poderemos extrair e conjecturar algumas propostas, sem, no entanto, descurarmos a quantidade e a qualidade informativa de tais documentos que, na maioria dos casos, é escassa para uma maior solidez nesse percurso. Avisados que estamos dessa limitação, não exclusiva desta personagem, podemos observar a presença amiúde de Ero Salídiz junto de membros da família Flaínez, concretamente, mas não só, de Pedro e do seu filho Fáfila Pérez e actuando igualmente num amplo raio de acção, mais abrangente em termos regionais do que se poderia esperar.

Podemos rastrear a sua presença até ao reinado de Afonso V, onde o vemos inserido num conjunto de personalidades dando testemunho à outorga da carta

${ }^{70}$ CAVERO DOMÍNGUEZ y LÓPEZ, 1999, vol. I: 287-289.

${ }^{71}$ Estamos limitados na abrangência desta nossa sugestão em virtude de somente possuirmos a regesta destes dois documentos, o que nos levanta igualmente algumas reservas sobre o eventual teor dos mesmos, pois, para além da serem ambos cronologicamente idênticos, enunciam-se doações sobre propriedades localizadas na mesma região, Vecilla de la Polvorosa. CAVERO DOMÍNGUEZ y LÓPEZ, 1999, vol. I: 244 e 244.

72 RUIZ ASENCIO, 1987, vol. III: 483-484.

${ }^{73}$ CAVERO DOMÍNGUEZ y LÓPEZ, 1999, vol. I: 244.

${ }^{74} \mathrm{Na}$ documentação da catedral de Astorga podemos encontrar várias religiosas a desempenhar tal cargo, quer antes, quer depois da mudança de titularidade, como Vellida em 960, Palmaria em 996, Canoria em 1009, Mansuara em 1052 e 1057, mas igualmente dois abades, Pedro Galendiz, em 1017 e Domingo em 1057, aparentemente coabitando com a citada Mansuara nesse mesmo ano. 
de delimitação do futuro couto do mosteiro de Santa Maria de Obona em Fevereiro de 1022, na região astur ${ }^{75}$. Dos presentes, sobressaem alguns dos nobres que irão de resto acompanhar o futuro Vermudo III, como Alvaro Ordones, Nepociano Osoriz, Pedro Flaíniz, Fáfila Pérez, entre outros, sendo estes dois últimos, companhia recorrente de Ero. Numa próxima notícia, e já reinado seguinte, a 28 de Março de 1032, e no seu regresso à região das Asturias, acompanhando, mais uma vez, todo um conjunto de membros da mais alta aristocracia do reino, como Álvaro Ordones, Fáfila Pérez, Pedro Laíns, etc., assiste à permuta de propriedades entre o rei de então e o conde Piniolo Jiménez com vista à ampliação patrimonial e fundiária do recém-fundado mosteiro de $\mathrm{S}$. João Baptista de Córias ${ }^{76}$, no entanto, o que sobressai desta permuta é a entrega de um conjunto largo de castelos por parte do conde Piniolo à pessoa do rei num ano de forte pressão política ${ }^{77}$.

Igualmente em 1032, mas em momento desconhecido, encontra-se Ero Salídiz, mais uma vez, inserido na comitiva real que se tinha deslocado à região a Noroeste de Leão, na área de influência do mosteiro de Otero de las Dueñas, com o intuito de restituírem a Fáfila Pérez uma sua propriedade que lhe teria sido subtraída anos antes por Jimena, esposa de Abdela Romaniz, em conjunto com os seus filhos, no contexto da transição dinástica ${ }^{78} \mathrm{~A}$ dita propriedade seria então parte de Villacesán, localizada junto do rio Cea, onde o próprio Abdela Romaniz seria igualmente proprietário de algumas herdades ${ }^{79}$, e que lhe fora doada por Vela Ovequiz, na casa de quem se teria educado ${ }^{80}$. Emprestam a sua assinatura, para além de Ero, o pai de Fáfila, Pedro Flaínez, o armiger real Nepociano Osores, o neto de Vermudo II, Álvaro Ordones, entre outros.

No ano seguinte, nessa mesma região do mosteiro de Otero de las Dueñas, mas em âmbito privativo, Ero Salítiz testemunha um acto de profiliação de um casal, Ermorigo e Columbra, a favor de Fáfila Pérez, em que ambos doam parte das suas herdades ${ }^{81}$, recebendo como compensação uma junta de bois. Após

75 SANZ FUENTES, 8 (Oviedo, 1995-1996): 301-302.

76 NÚÑEZ CONTRERAS, 8 (Sevilla, 1977): 79-81

77 «... In ripa de Selia, castro de Buraone, in Maliaio, castro de Sancta Maria, castro de Lugas, castro de Aquilare, castro de Souerrone, castro de Forte in plano, castro de la Isla...», in NÚÑ̃Z CONTRERAS, 8 (Sevilla, 1977): 79-81. Em termos estratégicos este conjunto de fortificações poderia não possuir a relevância de outros tempos, no entanto, como centros ordenadores do espaço continuariam a emanar uma influência bastante acertiva no conjunto populacional do seu entorno. Não deixa de ser significativa a sua mudança de propriedade num ano em que a autoridade de Sancho III seria reconhecida e percepcionada nas regiões centrais do reino leonês.

78 FERNÁNDEZ FLÓREZ y HERRERO DE LA FUENTE, 1999, vol. I: 293-295.

79 «Et alia terra per termino de Abdela Romanez...», in FERNÁNDEZ FLÓREZ y HERRERO DE LA FUENTE, 1999, vol. I: 208-210.

${ }^{80}$ FERNÁNDEZ FLÓREZ y HERRERO DE LA FUENTE, 1999, vol. I: 149-150.

${ }^{81}$ FERNÁNDEZ FLÓREZ y HERRERO DE LA FUENTE, 1999, vol. I: 295-296. 
este acto não voltaremos a ter notícias de Ero Salídiz durante o reinado de Vermudo III, somente reaparecendo na documentação aquando do reinado seguinte e somente depois da clarificação que a entrada em Leão proporcionou à nova dinastia. O próximo documento onde o iremos localizar será numa carta de doação ao mosteiro de Sahagún levada a efeito por Rodrigo Viátiz a 31 de Agosto de 1039, onde o mesmo irá conceder ao referido mosteiro propriedades localizadas no Ualle de Palaciolo ${ }^{82}$. Esta carta reveste-se de uma certa importância, pois, para além da presença de Ero, destaca-se igualmente o seu filho Vermudo Eriz entre as testemunhas presentes, configurando o primeiro acto público de elementos da sua prole, situação que doravante passará a ser recorrente.

Recorrente serão igualmente as doações de Rodrigo Viátiz ao mosteiro de Sahagún, incidindo maioritariamente ${ }^{83}$ sobre propriedades localizadas no citado Ualle de Palaciolo, na região do rio Tera, nas imediações do mosteiro de S. Salvador de Palazuelo ${ }^{84}$, onde Ero, ou somente os seus filhos ${ }^{85}$, se encontram como testemunhas. Em conjunto, apresentam-se no derradeiro diploma deste protagonista, lavrado anos mais tarde, a 31 de Agosto de 1050, onde, mais uma vez, este protagonista, em conjunto com a sua esposa Florentina, procede ao incremento fundiário do mosteiro de Sahagún com propriedades na mesma região ${ }^{86}$.

Igualmente em Sahagún, mas em momento anterior, neste caso a 1 de Maio de 1043, Ero e o seu filho Nepociano Eriz encontram-se como testemunhas de uma permuta de propriedades efectuada entre o conde Fernando Moniz e uma mulher de nome Marina, onde o primeiro concede todo um conjunto de herdades implantadas na região de Toro, e esta última somente duas, a uilla Tirso e a uilla Mauzale $^{87}$, situadas perto do Cea. De recordar que Fernando Moniz seria a autoridade condal em vários territórios a Leste de Leão, como Sanabria em Setembro de $1033^{88}$, Toro desde Março de $1040^{89}$, Astorga desde Setembro desse mesmo ano ${ }^{90}$ e Zamora em Outubro de $1049^{91}$, e na lista de confirmantes a sua assinatura

${ }^{82}$ HERRERO DE LA FUENTE, 1988, vol. II: 116-117.

${ }^{83}$ HERRERO DE LA FUENTE, 1988, vol. II: 177-179. Uma excepção será este diploma onde se especifica a entrada no património de Sahagún de algumas propriedades perto do rio Cea, como a Eglesia Alua, cum suos palazios, suos omines et suas ereditates.

${ }^{84}$ HERRERO DE LA FUENTE, 1988, vol. II: 58-59.

${ }^{85}$ HERRERO DE LA FUENTE, 1988, vol. II: 196-197. Documentalmente é a primeira vez que se observa a presença autónoma dos filhos de Ero Salídiz, neste caso, de Vermudo e Nepociano, não deixando de transparecer uma relativa estima social e influência regional desta estirpe de infanções, pois no diploma encontram-se igualmente alguns dos nobres de maior relevo, como Munio Afonso, Guterre Afonso e Flaíno Fernandes.

${ }^{86}$ HERRERO DE LA FUENTE, 1988, vol. II: 231-233.

${ }^{87}$ HERRERO DE LA FUENTE, 1988, vol. II: 142-144.

88 RODRÍGUEZ GONZÁLEZ, 39-40 (León, 1966): 225-226.

${ }^{89}$ HERRERO DE LA FUENTE, 1988, vol. II: 117-118.

${ }^{90}$ HERRERO DE LA FUENTE, 1988, vol. II: 118-120.

${ }^{91}$ HERRERO DE LA FUENTE, 1988, vol. II: 221-223. 
somente é antecedida pela dos filhos de Fernando Moniz, e de dois membros da família do antigo monarca Vermudo II, o que influi, mais uma vez, para a pertinência do seu relevo social. Após alguns anos de ausência documental, e novamente na companhia de um muito bem composto grupo de nobres ${ }^{92}$, elementos do clero episcopal e abacial, bem como, dos monarcas Fernando e Sancha, encontra-se Ero a testemunhar a 12 de Março de 1048 uma ampla doação de bens dispersos por toda a comarca de Astorga, levada a efeito pela condessa Teresa Moniz, viúva de Pedro Froilaz, conde do Bierzo, à igreja da referida comarca ${ }^{93}$.

Seguindo novamente o percurso no exterior da região de Astorga, a 27 de Outubro de 1049, e num documento já referido anteriormente, localiza-se com os seus filhos, Vermudo e Nepociano Eriz, a testemunhar no mosteiro de Eslonza uma ampla doação de propriedades que Pelágio Vermudes efectua aos reis de Leão ${ }^{94}$. Neste documento, para além da localização bastante fragmentada dessas propriedades, variando entre as Asturias e as imedieções do rio Esla, podemos constatar, até de forma bastante curiosa, a presença dos membros das principais famílias de infanções da região de Astorga. Com efeito, para além do já mencionado Rapinato Ectaz e dos filhos de Ero, Daniel Pelaiz, filho de Pelagio Danieliz ${ }^{95}$, Jimeno Lupiz, membro de uma conhecida família com presença assídua na documentação da catedral de Astorga, entre outros personagens de difícil identificação que pontuam igualmente esses documentos. Menos curioso, mas com semelhante atenção, será o facto de em primeiro plano se referenciarem alguns membros da alta nobreza, com destaque para os filhos de Ordonho Vermudes, filho bastardo do rei Vermudo II, como Vermudo Ordones, Afonso Ordones e Sancho Ordones. Os bispos de Leão e de Portucale, respectivamente, Cipriano e Sisnando ${ }^{96}$, encabeçam o lote de testemunhas deste acto levado a efeito por Pelagio Vermudes. Apesar dos nossos esforços e tendo em conta a ampla descrição da sua envolvente familiar não conseguimos rastrear de forma precisa a sua filiação e a subsequente interacção política e

92 Entre outros, elementos da família Flaínez e da família de Vermudo II.

${ }^{93}$ CAVERO DOMÍNGUEZ y LÓPEZ, 1999, vol. I: 262-265. Não deixa de ser curioso verificar no corpo do documento a menção e o apresso desta família pelo rei anterior, Vermudo III («incartavit mihi Rex meus Beremudus»), num documento, relembre-se, onde se encontra o rei de então, Fernando Magno. O facto do seu marido ter sido comite in terra Bergidensium é significativo da política de equilíbrio operada pela nova dinastia, sobretudo nestas terras de fronteira, no entanto, e se olhado de outro ângulo, esta presença real poderá somente significar o relevo a dar ao engrandecimento patrimonial da Sé de Astorga, principal veículo de contra-poder para com as ambições da aristocracia laica.

${ }_{94}$ RUIZ ASENCIO y RUIZ ALBI, 2007, vol 1: 117-121.

${ }_{95}$ Pelagio Danieliz seria o representante político no condado de Tera e sobre o qual iremos dedicar as próximas linhas, analisando o seu percurso e acção política.

${ }_{96}$ O bispo de Sisnando seria irmão de Monio Viegas, «fundador» da linhagem de RibaDouro, o que confere a esta estirpe de infanções um reconhecido prestigio político e social em terras de Portucale. MATTOSO, 1968: 76. EVANGELISTA MARQUES, 2017: 177-179. 
social deste membro da aristocracia, no entanto, a localização das propriedades fornecida pelo documento e a forma como algumas delas se foram incorporando no património familiar, fornecem-nos algumas pistas sobre a sua relevância social. Pelagio Vermudes detém propriedades disseminadas por uma geografia bastante abrangente, que podemos situar maioritariamente agrupadas em dois núcleos, um primeiro, a Norte da cidade de Leão, entre os rios Cureño, Porma e Esla ${ }^{97}$, e um segundo, mais expressivo, nas Astúrias, nos vales dos rios Nalón e Sela, onde no primeiro o seu pai, Vermudo Nunes, parece ter exercido algum grau de autoridade ${ }^{98}$.

Já aqui referimos o papel crescente dos filhos desta aristocracia regional, ganhando lugar e relevância nas várias composições notariais, quer em conjunto com os respectivos progenitores, quer isoladamente. E isoladamente, certamente em reconhecimento pela presença regional da sua família, será o contributo, ainda que votado ao insucesso, do filho de Ero, Nepociano Eriz, como testemunha abonatória de Munio Jiménez numa disputa com o bispo Diogo de Astorga pela posse do mosteiro de S. João de Toreno, em Setembro de $1054^{99}$. O bispo alegava que o referido mosteiro, bem como a propriedade onde o mesmo se situaria, a uilla vocabulo Toreno pertenceriam ao mosteiro de Santa Leocádia de Castañeda, em sentido oposto, Munio Jiménez invocava a sua posse. No sentido de dirimir este conflicto, as partes dirigem-se à presença dos monarcas, Fernando e Sancha, onde se arregimentam as testemunhas ${ }^{100} \mathrm{e}$ se irão esgrimir os argumentos que sustentem as respectivas alegações. Perante a apresentação de documentos por parte do bispo, Munio Jiménez assume a usurpação da casa clerical e pede perdão ${ }^{101}$. Por fim, a última presença documental de Ero Salídiz será a 4 de Maio de 1058 numa doação ao mosteiro de S. Salvador de Zotes del Páramo, levada a efeito por Martino e a sua esposa Munana, respectivos fundadores do dito cenóbio ${ }^{102}$.

\subsection{Pelágio Danieliz}

Vimos em parágrafos anteriores, aquando do julgamento sobre a posse devida do mosteiro de Santa Leocádia de Castañeda, que a existência de um

${ }^{97}$ RUIZ ASENCIO y RUIZ ALBI, 2007, vol 1: 117-121.

98 RUIZ ASENCIO y RUIZ ALBI, 2007, vol 1: 117-121.

99 CAVERO DOMÍNGUEZ y LÓPEZ, 1999, vol. I: 279-280.

100 «... vocem obtinentes de Monio Gemeniz, Roderico Osoriz et Didaco Moniz et Monio Pelagiz et Neptano Eriz...». Não no seu conjunto, mas separadamente, os nomes destas testemunhas pontuam vários documentos da catedral de Astorga, incluindo muitos onde intervêm membros das famílias de Ecta Rapinátiz e Ero Salídiz.

101 CAVERO DOMÍNGUEZ y LÓPEZ, 1999, vol. I: 279-280.

102 CAVERO DOMÍNGUEZ y LÓPEZ, 1999, vol. I: 294-296. 
título de propriedade irá desempenhar um papel de relevo em qualquer deligência jurídica, subvertendo e anulando a influência política e social que os respectivos intervenientes possam deter. Mais uma vez, os documentos da catedral de Astorga ilustram-nos um caso semelhante, onde o representante régio no condado de Riba de Tera, Pelágio Danieliz, procurava com anterioridade a Julho de 1033 a apropriação de terras pertencentes ao mosteiro local, o que poderia ser visto como mais um exemplo do comportamento de Ecta Rapinátiz e Ero Salídiz, no entanto, e ao contrário destes, a acção em si não obteve o sucesso desejado, pois os monges que com ele dirimiram a posse de tais propriedades possuíam as escrituras que atestavam a veracidade das suas alegações, levando à sua desistência ${ }^{103}$.

De resto, a família de Pelágio Danieliz encontrava-se bastante ligada àquela comarca, estando entre os membros da comunidade local que assistiram com doações à refundação do convento de Sta Marta de Tera, garantindo sustendo, quer para os monges, quer para a obra que agora se procurava erigir, através da entrega de um terreno que possuíam em Celadilla, nas imediações do castro de Camarzana, e efectuada em data incerta ${ }^{104}$. Esta informação que nos é parcialmente transmitida é parca para concluirmos sobre os patrocinadores de tal refundação, no entanto, e de acordo com os alguns documentos da catedral de Astorga, a sua família une-se na exclusividade de doações a Sta. Marta de Tera em anos vindouros, desconhecendo-se novas deslocações patrimoniais para outros cenóbios ${ }^{105}$. Apesar de emprestar essa generosidade, este aristocrata irá disputar com o seu abade e restante comunidade um pleito intermediado pelo rei Afonso V sobre a posse de um conjunto de propriedades, onde sobressai a herdade de Celadilla, em Abril de $1014^{106}$. Esta villa de Celadilla, ou o conjunto de propriedades que a compunham, irá tornar-se recorrente na acção da família, pois se no documento citado atrás podemos observar que a mesma estaria na sua posse, em virtude de uma doação efectuada por Afonso $\mathrm{V}$, através do apressuramento de um conjunto de propriedades a Ambrosio

103 CAVERO DOMÍNGUEZ y LÓPEZ, 1999, vol. I: 233.

104 CAVERO DOMÍNGUEZ y LÓPEZ, 1999, vol. I: 325. A data proposta pelos editores da colectânea documental, transcrita certamente do Índice das escrituras da catedral de Astorga, presente na Biblioteca Nacional de Espanha, encontra-se mal referenciada na medida em que Pelágio Danieliz já se encontrava morto desde, pelo menos, 1040 e de se documentar a existência de um mosteiro de invocação de Sta. Marta desde Dezembro de 1006 (CAVERO DOMÍNGUEZ y LÓPEZ, 1999, vol. I: 184). A nossa proposta para uma verosímil datação deste documento vai no sentido de se aproximar dos inícios do séc. XI, pois, anteriormente a 1006 nada consta sobre este mosteiro. De ressalvar o facto da existência de uma igreja de invocação de Sta Marta em Camarzana desde, pelo menos, o ano de 963 (CAVERO DOMÍNGUEZ y LÓPEZ, 1999, vol. I: 963). Sobre este assunto consultar: QUINTANA PRIETO, 5 (Barcelona, 1968): 65-106. GONZÁLEZ RODRÍGUEZ, 17 (Benavente, 2007): 75-115.

${ }^{105}$ CAVERO DOMÍNGUEZ y LÓPEZ, 1999, vol. I: 245 e 325.

106 CAVERO DOMÍNGUEZ y LÓPEZ, 1999, vol. I: 189. 
Ropariz; mais tarde, a 21 de Outubro de 1040, a sua viúva, Mumadona Gonsalviz, refere que a mesma teria sido comprada a Veila Zenequez e à sua esposa Xambila ${ }^{107}$.

Não possuímos os documentos originais, nem cópias credíveis dos mesmos, para se fazer o balanço sobre essas informações aparentemente contraditórias, no entanto, alargando o espectro da nossa visão para situações idênticas à que observámos, podemos depreender sobre a possível fragmentação dos titulares das propriedades que se agregavam na villa de Celadilla.

\section{Na Antiga GaLlecia}

Reorientando a nossa análise para poente, neste caso, para a região de influência do mosteiro de Samos, verificamos, embora de maneira aparentemente não tão dramática, a mesma interrupção na potestas real aquando da morte de Afonso V, tal como se pode observar num documento presente no cartório desse mosteiro, onde os condes Pedro e Vermudo Pinióliz, com as respectivas esposas, se apoderam de várias propriedades «... sine iussia patroni et sine caracteres et sine precio dato... $\rangle^{108}$, procurando posteriormente, a $13 \mathrm{em}$ Dezembro de 1058, os legítimos proprietários a sua restituição junto do rei. Observa-se igualmente, ainda que com algum distanciamento temporal às balizas estabelecidas para este estudo e apesar do poder que o cargo régio lhes concedia, alguns funcionários procuravam ampliar o seu património às custas de propriedade alheia, como se evidencia num pleito mantido pelo mosteiro contra o meirinho Ordonho Arias, relativo à usurpação por este último de uns homens que estariam vinculados à casa eclesiástica ${ }^{109}$.

Avançando na direcção a Santiago, iremos encontrar um dos mais expressivos episódios de violência registados documentalmente por estes dias, em que, num dado momento que ignoramos, mas certamente relacionado com o interregno dinástico que temos vindo a percorrer, Sisnando Galiarez, com a colaboração dos seus irmãos e demais cúmplices, empreendem as acções de pilhar, roubar, provocar homicídios e demais malfeitorias em certas propriedades que estariam na dependência da catedral e dos seus bispos, não concentradas necessariamente nas imediações da cidade ${ }^{110}$. A dimensão, o impacto e a violência dos mesmos foi de tal monta que o escrivão plasmou

107 CAVERO DOMÍNGUEZ y LÓPEZ, 1999, vol. I: 245.

108 LUCAS ÁLVAREZ, 1986: 458-461.

109 LUCAS ÁLVAREZ, 1986: 255-256.

110 Como, e a título de exemplo, uillam de Aocio (Oza dos Ríos, Betanzos), uillam de Salnes (Pontevedra) e monasterium de Ranariz (Santa María de Nebra, Porto do Son). LUCAS ÁLVAREZ, 1998: 158-160. 
esse espanto no documento em si, «... occiserunt homines, fecerunt rapinas multas... $\rangle^{111}$. Posteriormente, a 25 de Agosto de 1032, numa altura em que eventualmente a ordem já estaria restabelecida, o rei irá confiscar certo património pertencente a Sisnando Galiarez doando-o à respectiva Sé como compensação pelos danos causados.

Ao contrário das propriedades episcopais pilhadas, que se pautavam por uma relativa dispersão, as que lhe foram posteriormente subtraídas pela sua infidelidade concentram-se maioritariamente, para não dizer na totalidade ${ }^{112}$, em Teo, nos arredores da cidade. Tal acto e o volume em si, que até podemos eventualmente considerar proporcional aos desmandos perpetrados pela família Galiariz, não deixam de nos questionar sobre a pertinência e a concentração fundiária nos limites urbanos da cidade, configurando claramente uma generosa compensação ao seu bispo e à respectiva Sé $^{113}$, pois nelas encontram-se igualmente, como seus dependentes, todo um conjunto de população que garantem a rentabilidade dessas terras. Isto remete-nos, apesar da escassez documental, para uma certa relevância social de Sisnando (Sisnandus, filius Galiariz et neptus Menentii) que, e seguindo o mesmo padrão de Ecta Rapinátiz e Ero Salídiz que observámos linhas atrás, actua igualmente em conluio familiar.

Após este nosso olhar pelas terras mais setentrionais, iremos novamente atravessar o rio Minho em direcção ao territorio Portucalensis e observar a dinâmica proporcionada pela aristocracia local que, embora contendo pontos de contacto com o que falámos anteriormente, irá desembocar numa acção política, social e militar muito particular, contudo, as limitações físicas deste artigo obrigam-nos a ser demasiado sucintos para esta apaixonante complexidade.

Assim, e entrando na zona de contacto com as terras do Islão, neste caso, a região que se estende desde o rio Douro até à fronteira meridional proporcionada pelo Mondego e pela cidade de Coimbra, onde iremos encontrar, devido precisamente às características políticas destas regiões periféricas e excêntricas em relação ao poder central leonês, por parte dos condes de Coimbra, um comportamento semelhante ao do castelhano Garcia Gomes, ou seja, uma autonomização da sua potestas nas propriedades que directamente controlava e uma clara sustentação para as suas aspirações a outros territórios. Será neste contexto, e anos após as campanhas de Almançor nesta faixa portuguesa (995

\footnotetext{
111 LUCAS ÁLVAREZ, 1998: 158-160.

112 Excepção para Sanctum Micahelem de Barcala (A Estrada, Pontevedra). LUCAS ÁLVAREZ, 1998: 158-160.

${ }^{113}$ Não deixa de ser curioso o momento escolhido por Vermudo III para assim proceder, pois, e como já vimos, poucos dias depois, a 30 de Agosto de 1032, estará em Lugo a agraciar o seu bispo com a entrega do castro de Lapio, num ano de forte pressão por parte de Sancho III.
} 
e 997), que um membro da aristocracia condal portuguesa, Mendo Lucides, empreende uma campanha militar que culmina com a conquista do castelo de Montemor em $1017^{114}$, criando uma disrupção na fluidez do poder dos condes de Coimbra e dos seus aliados islâmicos na linha do Mondego. Para a sua posterior administração Mendo Lucides irá socorrer-se de Gonçalo Viegas ${ }^{115}$, membro da aristocracia local, com amplas propriedades localizadas entre os rios Douro e Vouga, e integrado na sua rede de dependentes ${ }^{116}$. Será a documentação a mostrar-nos de forma inequívoca o manto político que envolve este conjunto de acções e respectivos protagonistas: «... in diebus domno adefonso rex quando sedia in monte maiore de manu de ille rex...» $\mathrm{e}$ «... comes menendo luci qui illa terra inperaba sub gratia de ille rex domno adefonso.... $\rangle^{117}$.

Em claro contraste com este acontecimento, e avançando já para o reinado de Vermudo III, encontramos outro membro desta aristocracia local, Gonçalo Trastemires, a conquistar novamente Montemor em Novembro de $1034^{118}$, sem que se conheçam referências, quer aos condes, quer à coroa, levando-nos a conjecturar um amplo raio de autonomia proporcionada pela conjuntura política e social que então se vivia, e anos depois, certamente em reconhecimento dessa influência proporcionada pelas circunstâncias, o seu filho Mendo Gonçalves irá ser apodado, aquando da sua morte, como «uir illustris et magne potentie in toto Portugali ${ }^{119}$. Tanto quanto conhecemos, este reconhecimento cimeiro e abrangente territorialmente de uma personalidade que não pertencia a nenhuma parentela condal, será no mínimo inédita no conjunto leonês, no entanto, e tendo em conta as diversas vicissitudes pelas quais estas famílias passaram, nomeadamente a dos condes de Portucale, a sua aceitação insere-se num ambiente mais lato de uma crescente e rápida autonomização, respaldadas pela nova dinastia, dos membros destas famílias de natureza local.

Observamos na documentação essa percepção social, é certo que ao olhar dos homens da Igreja, como o facto de em Abril de 1050 numa acção judicial, e apesar do conde Mendo Nunes aparentemente não se encontrar diminuído das suas faculdades políticas, se afirmar que Gomes Ectaz detinha a autoridade em Portugal delegada pelos reis Fernando e Sancha ${ }^{120}$ e em Setembro de 1062, já com Nuno Mendes como conde portucalense, ser Godinho Viegas a desempenhar esse papel, mais uma vez sob delegação régia ${ }^{121}$. Julgamos, no entanto, que esse reconhecimento por parte de Fernando e Sancha da centralidade des-

\footnotetext{
114 PORTUGALIA MONUMENTA HISTORICA..., 1867, vol. I: 150-151.

115 MATTOSO, 1981a: 229-231.

116 PORTUGALIA MONUMENTA HISTORICA..., 1870, vol. III: 334.

117 PORTUGALIA MONUMENTA HISTORICA..., 1870, vol. III: 334.

118 DAVID, 1947: 295.

119 DAVID, 1947: 298.

120 PORTUGALIA MONUMENTA HISTORICA..., 1869, vol. II: 229.

121 LIBER FIDEI, 1965, tomo I: 51-53.
} 
tes infanções se encontra melhor plasmado na sua individualização perante outros magnates laicos e religiosos num documento emanado da sua cúria, onde se diz: «... illos infançones que erant in portugale Gomez eychiguiz, Men gunsaluiz et Gudio ueegas...» $\rangle^{122}$.

A par dessa autoridade administrativa que a monarquia lhes conferia, numa conjugação de mútuo interesse, podemos assinalar igualmente o mesmo padrão comportamental que já vimos nos vários grupos desta nobreza, como demonstra o longo litígio entre a sé de Santiago e um conjunto de infanções pela posse de várias propriedades nos arredores de Braga ${ }^{123}$; pela usurpação de parte do mosteiro de S. Pedro de Este pelo mesmo Godinho Viegas ${ }^{124}$ ou, entre muitos outros exemplos, pela tentativa frustrada de Garcia Moniz, governador do território de Anégia, de se apoderar do mosteiro de Soalhães (Marco de Canaveses) ${ }^{125}$.

Através destes pequenos apontamentos sumariamente acima analisados, a região charneira entre as terras leonesas e galegas, e na visão dos homens da Igreja, fora percorrida pela instabilidade decorrente da transferência dinástica, e se considerarmos o momento em que Vermudo III morreu, este período marcado pela instabilidade, terminou, ou pelo menos consolidou-se uma relativa estabilização ao nível da potestas do novo monarca, já identificável em Janeiro de 1053 onde podemos encontrar, mais uma vez, Fernando e Sancha em território português ${ }^{126}$. De assinalar igualmente o facto de, em Junho desse mesmo ano o bispo de Santiago, Cresconio, conduzir o infante Garcia até à Galiza, ficando responsável pela sua tutoria. Esta notícia será transmitida em pequena nota a finalizar um contrato de venda de umas herdades, não passando despercebida ao escrivão que a anotou em apenso como dado relevante, "In ista era LXL I leuauit episcubo domno Crisconio ad illo infante domno Garcia ad Galletia» ${ }^{127}$. Este comportamento de Fernando I, ao permitir que a educação do seu filho Garcia ficasse a cargo de um membro superior da Igreja (e com claras ramificações familiares de apoio ao anterior monarca), contrasta com o período passado, em casos semelhantes. Recordamos que Diogo Fernandes ficara responsável pela educação do futuro Ramiro II e Mendo Gonçalves tutor do infante Afonso, filho de Vermudo II.

A presença do infante em terras galegas comporta, a nosso ver, duas implicações imediatas na dinâmica política da antiga Gallecia. Uma primeira será a proximidade com a hierarquia eclesiástica, protegendo e ampliando as suas

\footnotetext{
122 PORTUGALIA MONUMENTA HISTORICA..., 1869, vol. II: 263.

${ }^{123}$ LUCAS ÁLVAREZ, 1998: 161; 1986: 162-163.

${ }^{124}$ LIBER FIDEI, 1965, tomo I: 222-223.

125 PORTUGALIA MONUMENTA HISTORICA..., 1869, vol. II: 263.

126 PORTUGALIA MONUMENTA HISTORICA..., 1869, vol. II: 234.

127 RUIZ ASENCIO, 1990, vol. IV: 286-288.
} 
propriedades, atendendo igualmente às suas reivindicações com préstimo ${ }^{128}$. Uma outra consequência e apesar da revolta da comitissa Odrocia e restante família a 19 Agosto de $1061^{129}$, prende-se com um conjuntural estado de pacificação social, garantindo-lhe o respaldo suficiente, em termos políticos e militares, para se dirigir às imediações de Burgos para defrontar o seu irmão Garcia na batalha de Atapuerca a 1 de Setembro de 1054, «... Fredinandus rex, collecto a finibus Gallecie immenso exercitu... $\rangle^{130}$.

\section{Conclusão}

Nestas linhas atrás observámos todo um conjunto de personalidades detentoras de autoridade, que, de uma maneira ou de outra, se prontificaram a usurpar propriedades alheias assim que toda uma conjuntura política e social lhes fosse favorável, como o breve interregno dinástico entre o falecimento de Afonso $\mathrm{V}$ e a sagração do seu filho. Em conjunto com este factor e talvez, na nossa opinião, o elemento decisivo para todo este processo, a persistente menoridade de Vermudo III que não lhe trouxe a decisiva e desejável consolidação no trono leonês para acomodar os diferentes interesses dos grupos nobiliários que gravitam no entorno régio. A essa menoridade régia opõem-se toda uma pressão política exercida por Sancho Garcês sobre as terras e respectivos intervenientes sociais, que há muito limitavam o reino leonês, trazendo alguma confusão na identidade do poder exercido em algumas comarcas, como Astorga.

Certamente que o tema é deveras complexo e estimulante, contudo, podemos apontar, ainda que de uma forma simples e escorreita, outros mecanismos de desorganização da ordem estabelecida, como a estagnação dos avanços na direcção das terras muçulmanas e a subsequente ocupação territorial, dando assim

128 BLANCO LOZANO, 1987: 104-107.

129 BLANCO LOZANO, 1987: 158-160. «... Odrocia comitissa... reuellauit nobis cum filia sua Giloira et cum nepus suum comitem Monnium Ruderici in nostros castellos Monte Roso, Grainilio, Alua de Buuale et Nouula, seditiones et scandalum mittens in terra Galletie...».

${ }^{130}$ HISTORIA SILENSE, 1921: 69-70. Mais adiante, podemos encontrar pormenores interessantes sobre o desenrolar da batalha, «... cum Fredinandi regis milites noctu desuper imminentem preoccupant collem», por exemplo. Sobre o significado concreto e a aplicabilidade prática da expressão «collecto a finibus Gallecie immenso exercitu», dificilmente, aquando do inicio da marcha para Burgos, Fernando I estaria acompanhado da totalidade das tropas que se alinharam em Atapuerca. Segundo o pouco que conhecemos do seu percurso (BLANCO LOZANO, 1987) o mesmo seguiria passando em regiões controladas por fideles seus, como, por exemplo, a região Astur (BLANCO LOZANO, 1987: 136-138). Ressalvando, no entanto, que para o ano de 1054 raros são os diplomas onde Fernando I e a sua esposa Sancha se encontram (SERRANO, 1925: 114-116). Neste último documento, como subscritores do mesmo, encontra-se uma plêiade de condes e aristocratas que habitualmente acompanham o rei, entre os quais, o armiger Pedro Peláez. 
respaldo às ambições de toda uma classe dirigente que se procurava afirmar; a tendência régia para a protecção de mosteiros e demais propriedades clericais, como um instrumento de travão às ambições dessa mesma nobreza, os infaziones terrae. Após a morte de Vermudo III e a identificação clara da sua irmã e do seu cunhado como legítimos herdeiros do trono de Leão, a par de uma nitida percepção da respectiva autoridade, trouxe um relativo apaziguamento social a estas terras ocidentais, não deixando a documentação de lhe fazer menção.

Constatámos igualmente que o percurso e os actos praticados por essa nobreza regional não se esgotam nos limites geográficos do seu entorno, mimetando, de certa maneira, o comportamento tradicional dos membros das famílias condais, de uma fluída mobilidade. Apesar de algumas zonas cinzentas ainda por descortinar, a sua presença nesse âmbito geográfico menos restrito, e tanto quanto a documentação nos permite conhecer, encontra-se aparentemente desligada da persecução fundiária privativa, encarnando, deste modo, uma influência política e social per se, justificando, assim, a sua presença junto de monarcas e demais membros da famíia real que os viam, nomeadamente a Ero Salídiz, um meio de garantirem algum balanço e influência na sempre delicada fronteira entre as terras leonesas e galegas, principalmente nestes tempos tão delicados.

Fugindo brevemente ao âmbito cronológico aqui proposto, mas deixando pistas para o futuro, que após a consolidação da dinastia Jimena em Leão, com o subsequente avanço para terras onde o Islão imperava, o percurso desses infaziones terrae se revela menos objectivo, desaparecendo paulatinamente da documentação, em contraste com o vivido em outras regiões do reino, nomeadamente nas terras portuguesas.

\section{Bibliogr afía}

Almeida Fernandes, Armando de, «Portugal no Período Vimaranense (868-1128)», Revista de Guimarães, 82 (Guimarães, 1972): 37-90.

Andrade Cernadas, José Miguel, O Tombo de Celanova: Estudio Introductorio, Edición e Índices (ss. IX-XII), Santiago de Compostela, Consello da Cultura Galega, 1995, tomos I y II.

Arteta, Antonio Ubieto, Cartulario de San Juan de La Peña, Valencia, Anúbar, 1962, vol. II.

Azevedo, Rui Pinto de, «A expedição de Almançor a Santiago de Compostela em 997, e a de piratas normandos à Galiza em 1015-1016», Revista Portuguesa de História, XIV (Coimbra, 1973): 91-92.

Baliñas Peres, Carlos, Defensores e traditores: um modelo de relación entre poder monárquico e oligarquia na Galicia altomedieval (718-1037), Santiago de Compostela, Xunta de Galicia, Consellería da Presidencia e Administración Pública, 1988.

Barros, Carlos, «Celanova de las Três Culturas, Siglos X-XI», in M. ${ }^{\text {a }}$ Isabel del Val Valdivieso e Pascual Martínez Sopena (dirs.), Castilla y el Mundo Feudal, vol. II, 
Homenaje al professor Julio Valdeón, Valladolid, Junta de Castilla y León/Universidad de Valladolid, 2009: 9-24.

Becerro Galicano de San Millán de la Cogolla (www.ehu.eus/galicano - consultado 14/02/1017).

Blanco Lozano, Pilar, Colección Diplomática de Fernando I (1037-1065), León, Centro de Estudios e Investigación «San Isidoro»/Archivo Histórico Diocesano, 1987.

Calleja Puerta, Miguel, El conde Suero Vermúdez, su parentela y su entorno social. La Aristocracia Asturleonesa em los siglos XI y XII, Oviedo, Ediciones KRK, 2001.

Carriedo Tejedo, Manuel, «Um merino leonés impuesto por Castilla: Fromarico Sendiniz (1010-1014)», Tierras de León. Revista de la Diputación Provincial, 22/48 (León, 1982): 59-68.

Cavero Domínguez, Gregoria y Martín López, Encarnación, Colección Documental de la Catedral de Astorga, vol. 1 (646-1126), León, Centro de Estudios e Investigación «San Isidoro»/Archivo Histórico Diocesano, 1999.

David, Pierre, Études historiques sur la Galice et le Portugal du VI au XII siècle, Lisbonne-Paris, 1947: 257-340.

Durany Castrillo, Mercedes y Rodríguez González, M. Carmen, «El obispado de Astorga en el primer tercio del siglo XI: de Jimeno a Sampiro», Sémata. Ciencias Sociais e Humanidades, 15 (Santiago de Compostela, 2003): 187-222.

Evangelista Marques, André, «A autoridade episcopal e a construção da rede paroquial na diocese do Porto (séculos X-XIV)», in Luís Carlos Amaral (coord.), Um Poder entre Poderes nos 900 anos da Restauração da Diocese do Porto e da Construção do Cabido Portucalense, Porto, Universidade Católica Portuguesa, 2017: 177-179.

Fernández del Pozo, José María, «Alfonso V, Rey de León. Estudio Histórico-Documental», León y su Historia. Miscelánea Histórica, V (León, 1984): 31-262.

Fernández Flórez, José Antonio y Herrero de la Fuente, Marta, Colección Documental del Monasterio de Santa María de Otero de Las Dueñas, vol. I (854-1108), León, Centro de Estudios e Investigación «San Isidoro»/Archivo Histórico Diocesano, 1999.

Ferreira Priegue, Elisa, «Mercaderes Gallegos de la Edad Media. Una aproximación pendiente», Sémapa. Ciencias Sociais e Humanidades, 12 (Santiago de Compostela, 2000): 19-34.

Flórez, Enrique, España Sagrada, Tomo XVI, «De la Santa Iglesia de Astorga», Madrid, Imprenta de D. Gabriel Ramírez, 1762.

García Larragueta, Santos, Colección Documentos de la Catedral de Oviedo, Oviedo, Instituto de Estudios Asturianos, 1962.

Gonzaga de Azevedo, Luís, História de Portugal, ed. preparada e revista por Domingos Maurício Gomes dos Santos, Lisboa, Edições Bíblion, 1939, vol. II.

González Rodríguez, Rafael, «Poblamiento medieval y estruturas de poder em el norte de Zamora. Algunas reflexiones em torno a Camazarna de Tera», Brigecio. Revista de Estudios de Benavente y sus Tierras, 17 (Benavente, 2007): 75-115.

Herrero de la Fuente, Marta, Colección Diplomática del Monasterio de Sahagún, vol. II (1000-1073), León, Centro de Estudios e Investigación «San Isidoro»/Archivo Histórico Diocesano, 1988. 
Historia Silense, Edição preparada por Francisco Santos Coco, Madrid, Junta para Ampliación de Estudios e Investigaciones Científicas, Centro de Estudios Históricos, 1921.

Isla Frez, Amancio, Realezas Hispánicas del Ano Mil, Santiago de Compostela, Publicacións do Seminario de Estudos Galegos/Ediciós do Castro, 1999.

Lacarra, José María, Historia Política del reino de Navarra desde sus Origenes hasta su incorporación a Castilla, Pamplona, Editorial Aranzadi, 1972, vol. I.

Liber Fidei, edição crítica por Avelino de Jesus da Costa, Braga, Junta Distrital de Braga, 1965, tomo I.

López Sangil, José Luis y Vidán Torreira, Manuel, «Tumbo Viejo de Lugo (transcripción completa)», Estudios Mindonienses. Anuario de Estudios Histórico-Teológicos de la Diócesis de Mondoñedo-Ferrol, 27 (Mondoñedo, 2011): 11-373.

Lucas Álvarez, Manuel, El Tumbo de San Julian de Samos (siglos VIII-XII), Santiago de Compostela, Caixa Galicia, 1986.

Lucas Álvarez, Manuel, Tumbo A de la Catedral de Santiago, Santiago, Seminario de Estudos Galegos/Cabildo de la S.A.M.I. Catedral, 1998.

Martín Iglesias, José Carlos, «Los Annales Castellani Antiquiores Annales Castellani Antiquiores y Annales Castellani Recentiores: edición y traducción anotada», Territorio, Sociedad y Poder. Revista de estudios medievales, 4 (Oviedo, 2009): 203-226.

Martínez Díez, Gonzalo, Sancho III, el Mayor. Rey de Pamplona, Rex Ibericus, Madrid, Marcial Pons-Historia, 2007.

Mattoso, José, Le Monachisme ibérique et Cluny. Les monastères du diocese de Porto de l'na mille à 1200, Louvain, Publications Universitaires de Louvain, 1968.

Mattoso, José, «A Nobreza Rural Portuense nos Séculos XI e XII», in A Nobreza Medieval Portuguesa. A Família e o Poder, Lisboa, Editorial Estampa, 1981a: 159-251.

Mattoso, José, «As Famílias Condais Portucalenses dos Séculos X e XI», in $A$ Nobreza Medieval Portuguesa. A Família e o Poder, Lisboa, Editorial Estampa, 1981b: 101-157.

Mattoso, José, Ricos-Homens, Infanções e cavaleiros. A nobreza medieval portuguesa nos séculos XI e XII, Lisboa, Guimarães Editores, 1998.

Mínguez, José María, Colección Diplomática del Monasterio de Sahagún, vol. I (Siglos $I X y X)$, León, Centro de Estudios e Investigación «San Isidoro»/Archivo Histórico Diocesano, 1976.

Núñez Contreras, Luis, «Colección Diplomatica de Vermudo III, Rey de León», in Historia. Instituiciones. Documentos, Sevilla, Editorial Universidad de Sevilla, 1977: 381-514.

Pérez, Mariel, «Monarquía, poderes feudales y potestas publica en el reino asturleonés», in Eleonora Dell'Elicine, Héctor Francisco, Paola Miceli y Alejandro Morin (coords.), Clientelismo, parentesco y cultura jurisdicional em las sociedades precapitalistas, Buenos Aires, Universidad Nacional General Sarmiento, 2014: 105-120.

Pérez, Mariel, «Aristocracia, monasterios y conflictos por la tierra. Reforma eclesiástica y relaciones sociales en León (siglos XI-XII)», Bulletin du centre d'études médiévales d'Auxerre/BUCEMA (em línea) 19/1 (2015), doi: 10.4000/cem.13899.

Portugalia Monumenta Historica, Diplomata et Chartae, Lisboa, Academia das Ciências de Lisboa, 1867 y 1969, vols. I y II.

Hispania, 2019, vol. LXXIX, nº 261, enero-abril, págs. 11-39, ISSN: 0018-2141, e-ISSN: 1988-8368

https://doi.org/10.3989/hispania.2019.001 
Quintana Prieto, Augusto, El Obispado de Astorga en los siglos IX y X, Astorga, Archivo Diocesano de Astorga, 1968.

Quintana Prieto, Augusto, «San Miguel de Camarzana y su Scriptorium», Anuario de Estudios Medievales, 5 (Barcelona, 1968): 65-106.

Quintana Prieto, Augusto, Tumbo Viejo de San Pedro de Montes, León, Centro de Estudios e Investigación «San Isidoro»/Archivo Histórico Diocesano, 1971.

Rey Caíña, José Angel, Colección Diplomatica de Ferreira de Pallares, Granada, Universidad de Granada, Facultad de Filosofia y Letras, 1985, vol. II.

Risco, Manuel, Espana Sagrada, Tomo XL, «Antiguedades de la Ciudad y Sta. Iglesia de Lugo», Madrid, Oficina de la Viuda e Hijo de Marín, 1796.

Rodríguez González, Ángel, «El Tumbo del Monasterio de San Martín de Castañeda», Archivos Leoneses. Revista de Estudios y Documentación de los Reinos Hispanos Occidentales, 39-40 (León, 1966): 181-352.

Rodríguez, Justiniano, «La Monarquía Leonesa de García I a Vermudo III (910-1037», El Reino de León en la Alta Edad Media, León, Centro de Estudios e Investigación «San Isidoro»/Archivo Histórico Diocesano, 1995, vol. III: 129-413.

Ruiz Asencio, José Manuel, «Rebeliones Leonesas contra Vermudo II», Archivos Leoneses. Revista de estudios y documentación de los reinos Hispano-Occidentales, 45-46 (León, 1969): 215-241.

Ruiz Asencio, José Manuel, Colección Documental del Archivo de la Catedral de León, vol. III (986-1031), León, Centro de Estudios e Investigación «San Isidoro»/ Archivo Histórico Diocesano, 1987.

Ruiz Asencio, José Manuel, Colección Documental del Archivo de la Catedral de León, vol. IV (1032-1109), León, Centro de Estudios e Investigación «San Isidoro»/ Archivo Histórico Diocesano, 1990.

Ruiz Asencio, José Manuel y Ruiz Albi, Irene, Colección Documental del Monasterio de San Pedro de Eslonza, vol. 1 (912-1300), León, Centro de Estudios e Investigación «San Isidoro»/Archivo Histórico Diocesano, 2007.

Sánchez-Albornoz, Claudio, «Los Judíos en los Reinos de Asturias y León (7321037)», in Viejos y Nuevos Estudios sobre las Instituciones Medievales Españolas, Madrid, Espasa-Calpe, 1980, tomo III: 1615-1630.

Sánchez Candeira, Alfonso, «La reina Velasquita de León y su descendencia», Hispania. Revista española de historia, 40 (Madrid, 1950): 449-505.

Sánchez Candeira, Alfonso, Castilla y León en el siglo XI. Estudio del Reinado de Fernando I, Edición de Rosa Montero Tejada, Madrid, Real Academia de la Historia, 1999.

Sanz Fuentes, M. Josefa, «Documentación Medieval del Monasterio de Santa María de Obona en el Archivo Histórico Diocesano de Oviedo», Asturiensia Medievalia, 8 (Oviedo, 1995-1996): 291-339.

Serrano, Luciano, Cartulario de San Pedro de Arlanza, Madrid, Junta para Ampliación de Estudios e Investigaciones Científicas, Centro de Estudios Históricos, 1925. 